\title{
HIGH-PERFORMANCE LIQUID CHROMATOGRAPHIC ESTIMATION METHOD FOR TRANSDERMAL DIFFUSION STUDY OF GRANISETRON
}

\author{
RAMA BUKKA*, CHAYA HN \\ Department of Pharmaceutics, Nargund College of Pharmacy, Bengaluru, Karnataka, India. E-mail: ramabukka@gmail.com
}

Received: 18 January 2021, Revised and Accepted: 22 February 2021

\section{ABSTRACT}

Objective: The study is aimed to develop a simple, isocratic and sensitive reversed-phase high-performance liquid chromatography method for the analysis of granisetron during transdermal permeation studies through porcine ear epithelium.

Methods: A reversed-phase (C18) column was used with ultraviolet detection at $210 \mathrm{~nm}$. Selected mobile phase contained $25 \%$ (v/v) of acetonitrile and $75 \%(\mathrm{v} / \mathrm{v})$ of $0.25 \mathrm{mM}$ potassium dihydrogen orthophosphate solution $\mathrm{pH}$ adjusted to 3.0 using $1 \%$ orthophosphoric acid solution.

Results: Calibration curve showed good linearity over $0.1-30 \mu \mathrm{g} / \mathrm{mL}$ concentration range of porcine ear permeates in $80 \%$ ethanol and $20 \%$ water (blank permeates). The applicability of the method was demonstrated by the analysis of diffusion study samples of granisetron through porcine ear epithelium and the steady-state permeability flux (J) from ethanolic solution was found to be $4.707 \mu \mathrm{g} / \mathrm{square} \mathrm{cm} / \mathrm{h}$.

Conclusion: The developed method can be used in the analysis of diffusion study samples of granisetron transdermal formulations through the porcine ear epithelium.

Keywords: Reversed-phase high-performance liquid chromatography, Flux, Transdermal, Porcine ear, Granisetron.

(C) 2021 The Authors. Published by Innovare Academic Sciences Pvt Ltd. This is an open access article under the CC BY license (http://creativecommons.org/ licenses/by/4.0/) DOI: http://dx.doi.org/10.22159/ajpcr.2021v14i4.40832. Journal homepage: https://innovareacademics.in/journals/index.php/ajpcr

\section{INTRODUCTION}

Granisetron is used in the treatment or prophylaxis of emesis and nausea. It is a 5-HT3 receptor antagonist indicated to treat vomiting caused by cancer chemotherapy and radiation therapy or nausea induced during post-operative care. It works by blocking serotonin, a natural substance in the body that causes nausea and vomiting [1].

The prime therapeutic regimens for treating cancer are associated with most distressing and common adverse effects of nausea and vomiting which cause many clinical implications for patients, including unwillingness or inability to eat and/or drink leading to nutritional deficits which may lead to non-compliance with treatment. Hence, nausea and vomiting need to be prevented from the start of chemotherapy so that participation and co-operation of the patient during the subsequent cycles of the chemotherapy can be expected [2]. At present, many antiemetic drugs are being prescribed to prevent nausea and vomiting. The side effects of emesis are not just unpleasant condition, and they can lead to serious dehydration and even malnutrition. The pulsatile nature of oral delivery may also cause problems resulting from deviations from the therapeutic window. In addition, oral route may not be suitable for patients suffering from nausea and vomiting. Hence, post-chemotherapy and post-operative care and transdermal antiemetic therapy have the potential to ease the suffering of patients who are not only experiencing nausea and vomiting, resulting from their primary therapy but also experiencing significant discomfort associated with their medical condition per se [3]. The promising method to diminish its adverse effects is to deliver the drug through skin.

The present study can be used as estimation method for the transdermal diffusion study of granisetron base through porcine ear epithelium.

\section{MATERIALS}

Granisetron base was kindly donated by Dr. Reddys Laboratories Ltd., Hyderabad. High-performance liquid chromatography (HPLC) grade solvents were purchased from Ranbaxy Fine Chemicals Ltd., New Delhi. Porcine ear tissue obtained from local slaughter house.

\section{METHODS}

Chromatographic conditions

The apparatus used for the HPLC analysis was Shimadzu LC equipped with LC 20 AT prominence liquid chromatograph pump and a Shimadzu SPD-20A ultraviolet (UV) prominence UV/Vis detector. A chromasol ONYX ( $4.6 \mathrm{~mm} \times 250 \mathrm{~mm}$; $5 \mu \mathrm{m}$ particle size) C 18 column was employed during the analysis. An isocratic method was used with a mobile phase containing a mixture of acetonitrile $25 \%$ and $75 \%$ of $0.25 \mathrm{mM}$ potassium dihydrogen orthophosphate solution $\mathrm{pH}$ adjusted to 3.0 using $1 \%$ orthophosphoric acid solution. The mobile phase was vacuum-filtered through $0.45 \mu \mathrm{m}$ Millipore membrane and degassed by ultrasonicaton. The injection volume was $20 \mu \mathrm{L}$. After equilibration with the solvent to obtain a stable baseline, aliquots of calibration solutions containing internal standard were injected. Domperidone was selected as internal standard. The total run time was $10 \mathrm{~min}$. The absorbance of the eluent was monitored at $210 \mathrm{~nm}$ with a detection sensitivity of 0.250 aufs. All the analysis was performed at room temperature.

\section{Preparation of blank permeates}

Porcine ear tissue was used in diffusion study as pork ear tissue was qualitatively and quantitatively similar when compared with human skin $[4,5]$. It was obtained from a local slaughter house immediately after pigs were slaughtered. Ear tissue of freshly slaughtered pigs was immediately transferred to our laboratory. The dorsal hair was removed with a clipper and full-thickness skin was surgically removed using micro-dissecting scissor and blunt forceps. Then, the ear skin was dipped into the hot water (at $60^{\circ} \mathrm{C}$ ) and followed by fat removal to get epidermis which was washed with water and used in permeation studies. The permeation studies were initiated within an hour of isolating ear epithelium. Since the method was indicated to be used for transdermal permeation study through porcine ear tissue, to avoid the interference from the tissue permeates with the drug and internal standard, the blank tissue permeates (blank 
permeates) were prepared by placing the porcine ear epidermis in Franz diffusion cell between donor and receptors and clamped with the help of rubber bands, and $80 \%$ ethanol and $20 \%$ double distilled water were added in the donor $(5 \mathrm{~mL})$ as well as receptor compartment $(35 \mathrm{~mL})$ of the diffusion cells and taking care to avoid the entry of air bubbles. Magnetic bead was added in the receptor to maintain stirring conditions. The entire setup was placed over magnetic stirrer and the temperature was maintained at $37^{\circ} \mathrm{C}$ by placing the diffusion cell in a water bath for $24 \mathrm{~h}$ at $37^{\circ} \mathrm{C}$. The permeates collected after $24 \mathrm{~h}$ were used as diluent for the preparation of calibration standards to eliminate any interference of the components which were eluted during diffusions study.

Preparation of calibration Standards for HPLC estimation of granisetron

In this method, internal standard was also added in a constant amount to calibration samples which will correct for various sources of volume errors during sample preparation and injection [6]. Domperidone was selected as an internal standard.

Standard stock solution I of granisetron and Domperidone $(1 \mathrm{mg} / \mathrm{ml})$ were prepared in methanol. Stock solution II and III of granisetron of $100 \mu \mathrm{g} / \mathrm{mL}$ and $10 \mu \mathrm{g} / \mathrm{mL}$ were prepared by dilution of stock I solution using mobile phase. Similarly, stock solution II of domperidone of $50 \mu \mathrm{g} / \mathrm{mL}$ was prepared using the mobile phase.

From the stock solution III of granisetron, aliquots of 0.1 and $0.5 \mathrm{ml}$ were diluted to $10 \mathrm{ml}$ using blank permeates of porcine ear tissue after adding $1 \mathrm{ml}$ of stock II solution of domperidone ( $50 \mu \mathrm{g} / \mathrm{mL}$ ), resulted in calibration sample for 0.1 and $0.5 \mu \mathrm{g} / \mathrm{mL}$ granisetron and $5 \mu \mathrm{g} / \mathrm{mL}$ domperidone, respectively. Similarly, calibration samples of $1,5,10$, and $30 \mu \mathrm{g} / \mathrm{mL}$ were prepared using stock II solution of granisetron and stock II solution of domperidone. Samples for calibration curve were prepared such that each $\mathrm{ml}$ will have $0.1,0.5,1,5,10$, and $30 \mu \mathrm{g} / \mathrm{mL}$ of granisetron and a fixed $5 \mu \mathrm{g} / \mathrm{mL}$ of domperidone in all the samples. The prepared calibration standards were analyzed after filtering through $0.45 \mu \mathrm{m}$ Millipore membrane filter.

As some of the tissue components will also diffuse into the receptor compartment during the diffusion study and which are found to be eluted in a time range of 1-3 min, the mobile phase was selected to give a retention time of $>3 \mathrm{~min}$ for the drug.

The mobile phase and calibration standards were freshly prepared on the day of usage.

Ex-vivo permeation study of granisetron from solution through porcine ear tissue

The Franz diffusion cells are thoroughly cleaned with DW. As per the method mentioned in the preparation of blank permeates, ear epidermis was separated and clamped between donor and receptor cells of diffusion cell. The permeation studies were initiated within $1 \mathrm{~h}$ of isolating ear epithelium. $80 \%$ of ethanol and $20 \%$ of double-distilled water were filled into the receptor and air bubbles were totally removed from the receptor. The tissue mounting internal surface area of the diffusion cell was 4.9 square $\mathrm{cm}$. Hence, to incorporate $1 \mathrm{mg}$ of drug per square $\mathrm{cm}, 1 \mathrm{ml}$ of $4.9 \mathrm{mg} / \mathrm{ml}$ of granisetron solution in $80 \%$ ethanol and $20 \%$ water was added into the donor cell. Then, the entire setup was placed over magnetic stirrer, and temperature was maintained at $37^{\circ} \mathrm{C}$ by placing the diffusion cell in a water bath for $24 \mathrm{~h}$ at $37^{\circ} \mathrm{C}$. Then, $1 \mathrm{ml}$ of sample was withdrawn from the bottom portion of receptor using syringe fitted with a catheter, at $1,2,4,6,8,12$, and $16 \mathrm{~h}$ and replaced with $1 \mathrm{ml}$ of receptor fluid immediately after every sample withdrawal.

For estimation of granisetron in the permeation sample, $0.1 \mathrm{ml}$ of permeate was added with $0.1 \mathrm{ml}$ of I.S. solution $(50 \mu \mathrm{g} / \mathrm{ml})$. The volume was made up to $1 \mathrm{ml}$ with mobile phase. This sample was filtered using $0.2 \mu \mathrm{m}$ Millipore membrane filter before injected into HPLC.

The flux $\left(\mu \mathrm{g} / \mathrm{cm}^{2} \mathrm{~h}\right)$ of granisetron was calculated from the slope of graph of the cumulative amount of granisetron permeated per $\mathrm{cm}^{2}$ of pig ear epidermis at steady-state against the time using linear regression analysis [7].

\section{RESULTS AND DISCUSSION}

The present study was planned to use active drug granisetron in its base form than its hydrochloride salt form as it is anticipated that free base form will have greater skin permeability than its corresponding salt form [8]. It is widely believed that passive transdermal diffusion occurs predominantly through the lipid phase of the skin due to the continuous lipid regions in the stratum corneum $[9,10]$. Therefore, hydrophobic drugs usually have better permeability across the skin than water-soluble ionic or hydrophilic drugs [11].

Granisetron hydrochloride is soluble in water with molecular weight of $348.9 \mathrm{~g} / \mathrm{mol}$ compared to granisetron base which is insoluble in water and freely soluble in methanol and methylene dichloride and molecular weight of $312.4 \mathrm{~g} / \mathrm{mol}$, and $\log$ P value of granisetron base was 2.8 [12].

Many of the commercially approved molecules had log $\mathrm{P}$ values between 1 and 3 and had molecular weight less than 500 Da [13]. In this connection, granisetron base will be more suitable for transdermal administration than its corresponding salt form.

Literature also reveals the use of granisetron base as the active substance in preference to granisetron hydrochloride (currently marketed oral and intravenous formulations use hydrochloride salt form of the drug as described by a Ph. Eur. monograph) because of anticipated superior skin permeation properties. Granisetron base is lipophilic, non-ionic drug substance, and due to its physical/chemical properties, it is more suitable for the preparation of transdermal dosage forms and for appropriate penetration through the skin [12]. However, many studies on granisetron percutaneous absorption were performed on hydrophilic granisetron hydrochloride instead of the lipophilic granisetron free base [14,15], and to achieve a better permeation profile, granisetron base form was employed in another study [16].

\section{Calibration curve of granisetron by HPLC}

The standard graph was found to be linear in the range of $0.1-30 \mu \mathrm{g} / \mathrm{ml}$. The $\mathrm{R}^{2}$ and the slope (Y) were found to be 0.9987 and 0. 0.0664, respectively. The values are presented in Table 1 and Fig. 1 .

Table 1: Calibration curve of granisetron using domperidone as internal standard by high-performance liquid chromatography

\begin{tabular}{lll}
\hline S. No. & $\begin{array}{l}\text { Concentration } \\
(\boldsymbol{\mu} \mathbf{g} / \mathbf{m l})\end{array}$ & $\begin{array}{l}\text { Mean Ratio } \pm \mathbf{s ~ d ~ ( n = 3 ) ~} \\
\text { (Granisetron/Domperidone) }\end{array}$ \\
\hline 1 & 0.1 & $0.036 \pm 0.000759$ \\
2 & 0.5 & $0.046 \pm 0.001069$ \\
3 & 1 & $0.069 \pm 0.001082$ \\
4 & 5 & $0.539 \pm 0.013452$ \\
5 & 10 & $0.728 \pm 0.006537$ \\
6 & 30 & $1.971 \pm 0.008272$ \\
\hline
\end{tabular}

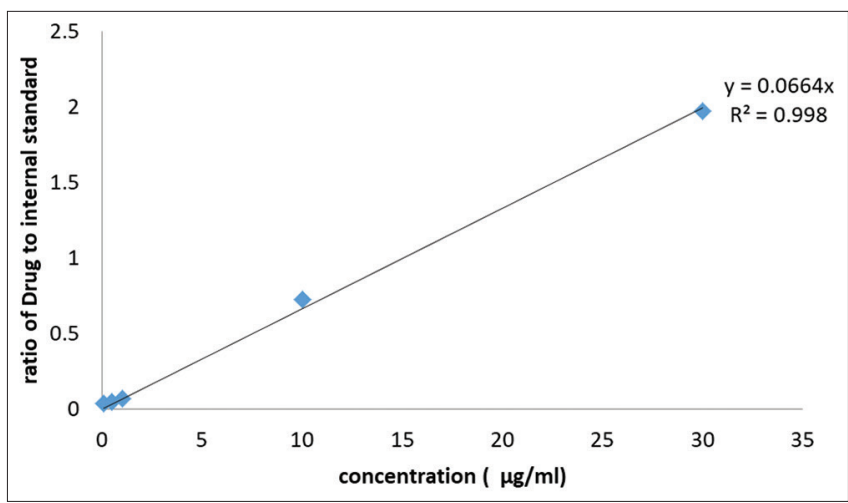

Figure 1: Calibration curve of granisetron using domperidone as internal standard by high-performance liquid chromatography 


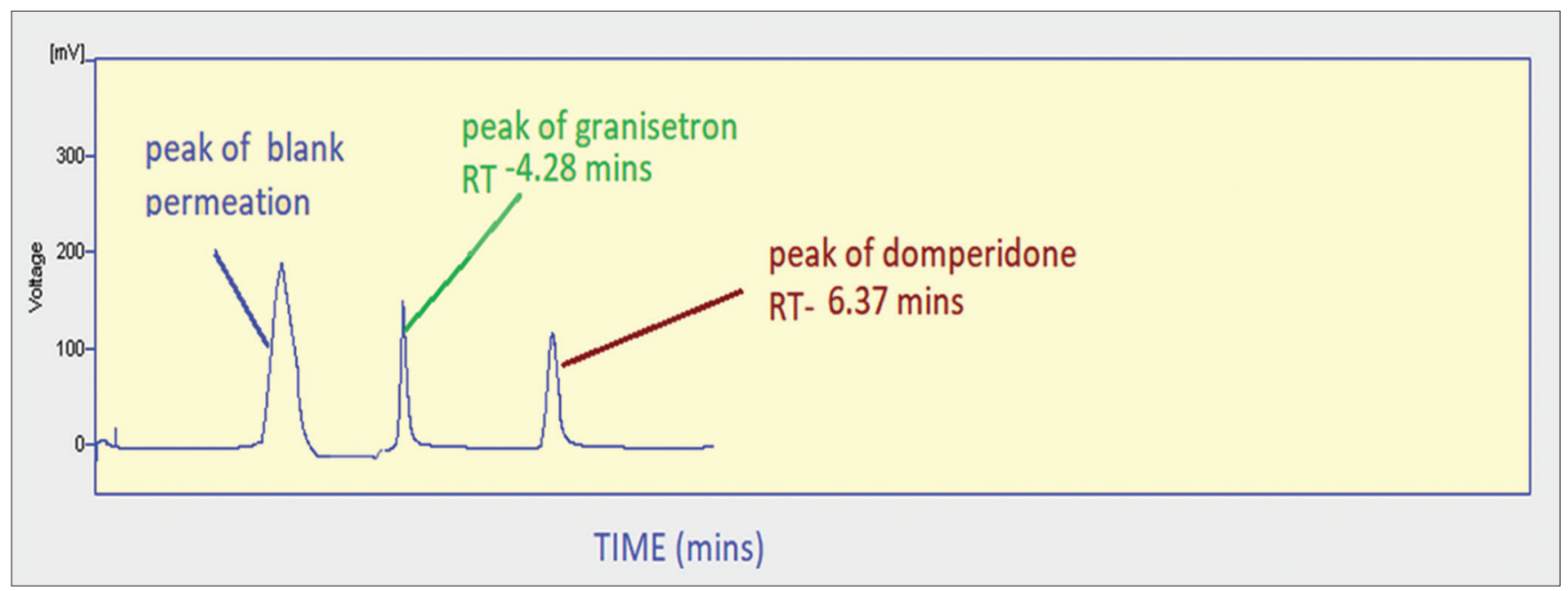

Figure 2: Model high-performance liquid chromatography chromatogram of granisetron in ex-vivo diffusion study through porcine ear epithelium using domperidone as internal standard

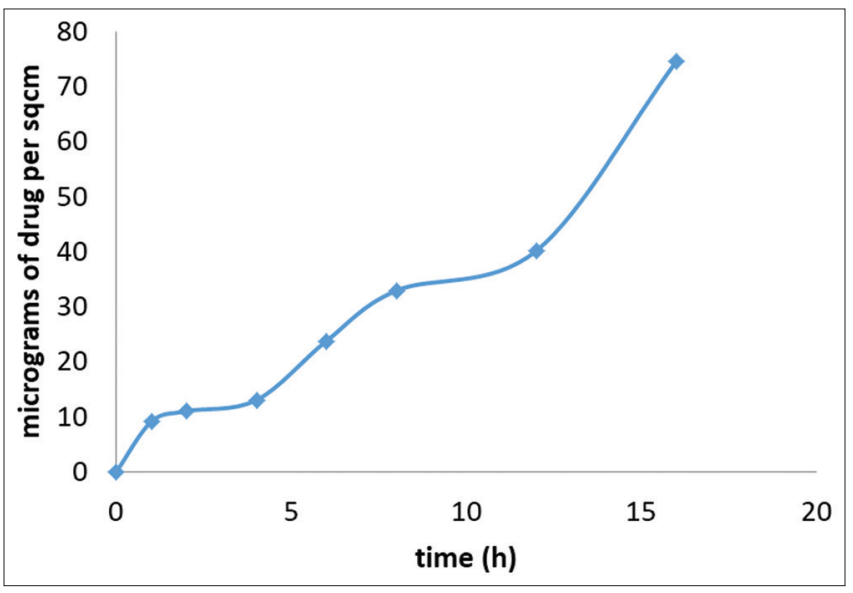

Figure 3: Graph of ex-vivo diffusion study of granisetron through porcine ear epithelium

Table 2: Ex-vivo diffusion study of granisetron through porcine ear epithelium

\begin{tabular}{ll}
\hline Time (hours) & $\begin{array}{l}\text { Micrograms of drug permeated } \\
\text { per square } \mathbf{c m}(\mathbf{m e a n} \pm \mathbf{S D}) \mathbf{n}=\mathbf{4}\end{array}$ \\
\hline 0 & 0 \\
1 & $9.095888 \pm 1.048857$ \\
2 & $11.84 \pm 0.21189$ \\
4 & $13.68 \pm 0.20293$ \\
6 & $23.75788 \pm 1.778916$ \\
8 & $32.92285 \pm 1.113523$ \\
12 & $40.16795 \pm 1.888021$ \\
16 & $74.6284 \pm 6.174837$ \\
\hline
\end{tabular}

Ex-vivo diffusion study of granisetron from solution through porcine ear tissue

The sample analysis of diffusion study of granisetron solution through ear epithelium was done using the developed HPLC method. The peaks due to tissue components which were diffused into receptor showed retention time around $2 \mathrm{~min}$. Retention time of granisetron was observed at $4.2 \mathrm{~min}$, and peaks due to domperidone (I.S) were observed at $6.3 \mathrm{~min}$. During the diffusion study some of the tissue components also will diffuse down into the receptor compartments along with drug and may interfere with the peaks of drug and internal standard. To avoid such interference, blank tissue permeates were used in standard graph preparation. The mobile phase was selected to give a retention time of $>3.5 \mathrm{~min}$ for the drug. The method was selective, specific for drug and internal standard. The model chromatogram is shown in the Fig. 2.

The values of diffusion studies are shown in Table 2 and Fig. 3. The flux (J) observed when $1 \mathrm{mg} / \mathrm{square} \mathrm{cm}$ was added to donor was found to be $4.707 \mu \mathrm{g} / \mathrm{square} \mathrm{cm} / \mathrm{h}$.

\section{CONCLUSION}

A simple, isocratic, and sensitive HPLC method was developed to estimate the granisetron concentration in diffusion study using porcine ear epithelium at a donor concentration of $1 \mathrm{mg} / \mathrm{square} \mathrm{cm}$ drug concentration was developed.

Ex-vivo diffusion study was carried out to check the permeation of drug through porcine ear epithelium. The flux was found to be 4.707 $\mu \mathrm{g} / \mathrm{square} \mathrm{cm} / \mathrm{h}$ during the diffusion study. The developed method can be used to estimate granisetron concentrations in diffusion studies of transdermal formulations.

\section{ACKNOWLEDGMENTS}

We, the authors, gratefully thank Rajiv Gandhi university of Health sciences, Bengaluru, Karnataka, for providing us the required financial support for carrying out this research project under RGUHS advanced research grants. We are also thankful to principal, Nargund college of Pharmacy, Bengaluru, for providing the necessary support and facilities.

\section{AUTHORS CONTRIBUTION}

Dr. Rama Bukka is the Principal investigator and Chaya $\mathrm{H} \mathrm{N}$ is the coinvestigator of the research project.

\section{CONFLICTS OF INTEREST}

There were no conflicts of interest among the authors regarding the research and publication of this work.

\section{AUTHORS FUNDING}

Authors received funding from Rajiv Gandhi University of health sciences, Bengaluru, Karnataka, under advanced research Grants.

\section{REFERENCES}

1. Hsu ES. A review of granisetron, 5-hydroxytryptamine3 receptor antagonists, and other antiemetics. Am J Ther 2010;17:476-86. 
2. Schnell FM. Chemotherapy-induced nausea and vomiting: The importance of acute antiemetic control. Oncologist 2003;8:187-98.

3. Julie LR. Treatment of chemotherapy-induced nausea in cancer patients. Eur Oncol 2010;6:14-6.

4. Jacobi U, Kaiser M, Toll R, Mangelsdorf S, Audring H, Otberg N, et al. Porcine ear skin: An in vitro model for human skin. Skin Res Technol 2007;13:19-24.

5. Dick IP, Scott RC. Pig ear skin as an in-vitro model for human skin permeability. J Pharm Pharmacol 1992;44:640-5.

6. Ohtaka R, Maeda M, Iwagami T, Ueda T, Kimura Y, Imai K, et al. Precision of internal standard method in HPLC analysis. Yakugaku Zasshi 2003;123:349-55.

7. Krishnaiah YS, Al-Saidan SM, Chandrasekhar DV, Rama B. Effect of nerodilol and carvone on in vitro permeation of nicorandil across rat epidermal membrane. Drug Dev Ind Pharm 2008;32:423-35.

8. Therapeutic Goods Administration. Australian Public Assessment Report for Granisetron. Australia: Therapeutic Goods Administration; 2011. p. 1-60. Available from: https://www.tga.gov.au/node/799

9. Ranade VV. Drug delivery systems. 6. Transdermal drug delivery. J Clin Pharmacol 1991;31:401-18.

10. Johnson ME, Blankschtein D, Langer R. Evaluation of solute permeation through the Stratum corneum: Lateral bilayer diffusion as the primary transport mechanism. J Pharm Sci 1997;86:1162-72.

11. Lee CK, Uchida T, Kitagawa K, Yagi A, Kim NS, Goto S. Skin permeability of various drugs with different lipophilicity. J Pharm Sci 1994;83:562-5.

12. Assessment Report: Sancuso, INN-granisetron. Vol. 44; 2012. Available from: http://www.ema.europa.eu/docs/en_GB/document_library/ EPAR - Public assessment report/human/002296/WC500127130.pdf.

13. Alkilani $\overline{A Z}, \mathrm{McC}$ rudden MT, Donnelly RF. Transdermal drug delivery: Innovative pharmaceutical developments based on disruption of the barrier properties of the Stratum corneum. Pharmaceutics 2015;7:438-70.

14. Woo JS. Nasal absorption studies of granisetron in rats using a validated high-performance liquid chromatographic method with mass spectrometric detection. Arch Pharm Res 2006;30:778-84.

15. Zheng WW, Zhao L, Wei YM, Ye Y, Xiao SH. Preparation and the in vitro evaluation of nanoemulsion system for the transdermal delivery of granisetron hydrochloride. Chem Pharm Bull (Tokyo) 2010;58:1015-9.

16. Zhao N, Cun D, Li W, Ma X, Sun L, Xi H, et al. In vitro percutaneous absorption enhancement of granisetron by chemical penetration enhancers. Drug Dev Ind Pharm 2013;39:561-8. 